\title{
TINJAUAN KRITIS TERHADAP PUTUSAN PRAPERADILAN ATAS TIDAK SAHNYA PENETAPAN TERSANGKA TINDAK PIDANA KORUPSI (Studi Kasus Putusan Nomor: 97/Pid.Prap/2017/PN.Jkt.Sel)
}

\section{Maria Prehatiningsih Utami, Hidayatullah dan Wiwit Ariyani}

Email : mariautami7@gmail.com, hidayatullah@umk.ac.id,wiwit.ariyani@umk.ac.id Fakultas Hukum Universitas Muria Kudus

\begin{abstract}
ABSTRAK
Tinjauan Kritis terhadap Putusan Praperadilan atas Tidak Sahnya Penetapan Tersangka Tindak Pidana Korupsi (Studi Kasus Putusan Nomor: 97/Pid.Prap/2017/PN.Jkt.Sel.) ini, secara umum bertujuan untuk mengetahui penyelidikan dan penyidikan tindak pidana korupsi yang dilakukan oleh Komisi Pemberantasan Korupsi dan alat bukti yang digunakan oleh Komisi Pemberantasan Korupsi pada tahap penyelidikan dan penyidikan untuk menetapakan status seseorang sebagai tersangka tindak pidana korupsi. Hasil penelitian menunjukkan bahwa suatu penyelidikan dapat digunakan sebagai dasar untuk melakukan penyidikan dan penetapan tersangka terhadap beberapa orang, apabila pada saat penyelidikan telah diketahui bahwa tindak pidana korupsi dilakukan secara bersama-sama atau terdapat unsur turut serta dalam perwujudan delik korupsi. Penyelidikan maupun penyidikan terhadap tindak pidana korupsi dianggap sah apabila memenuhi ketentuan dalam KUHAP, UU No. 31 Tahun 1999 yang selanjutnya diubah melalui UU No. 20 Tahun 2001 dan UU No. 30 Tahun 2002 serta memenuhi administrasi penyelidikan dan penyidikan. Mengenai alat bukti yang digunakan sebagai dasar untuk menetapkan seseorang sebagai tersangka dapat menggunakan alat bukti yang ditemukan pada penyelidikan dan penyidikan orang lain. Penggunaan alat bukti dari perkara orang lain adalah sah dengan memperhatikan parameter bewijsmiddelen-bewijsminimmum, bewijsvoering dan bewijskracht.
\end{abstract}

Kata Kunci: Putusan Praperadilan, Penetapan Tersangka,Tindak Pidana Korupsi 


\section{PENDAHULUAN}

Ikrar Indonesia sebagai negara hukum yang dalam penyelenggaraannya menganut prinsip rule of law, mendudukkan hak asasi manusia sebagai elemen penting untuk dilindungi. Praperadilan hadir sebagai bentuk perlindungan hak asasi manusia dalam sistem peradilan pidana. Praperadilan diatur dalam Pasal 1 angka 10 KUHAP dan Pasal 77-83 KUHAP. Berdasarkan ketentuan yang ada dalam KUHAP, kewenangan praperadilan meliputi pemeriksaan keabsahan penangkapan dan penahanan, keabsahan penghentian penyidikan dan penghentian penuntutan serta permintaan ganti kerugian atau rehabilitasi.

Pada perkembangannya, pasca lahirnya Putusan Mahkamah Konstitusi Nomor 21/PUU-XII/2014, kewenangan praperadilan mengalami perluasan termasuk pada pemeriksaan keabsahan penetapan Tersangka, keabsahan penyitaan dan penggeladahan. Akibat dari putusan a quo, maka intensitas perkara yang menguji keabsahan penetapan Tersangka meningkat, khususnya pada tindak pidana korupsi. Putusan praperadilan yang memutus bahwa penetapan Tersangka tindak pidana korupsi tidak sah, tidak luput dari perhatian publik. Selain dikarenakan pada, ratio decidendi Hakim yang dianggap mengandung kejanggalan juga mekanisme beracara praperadilan yang tidak diatur secara komprehensif.

Berdasarkan Pasal 83 ayat (1) KUHAP, Putusan MK No. 65/PUUIX/2011, Pasal 45A UU No. 5 Tahun 2004 jo. UU No. 3 Tahun 2009 dan PERMA No. 4 Tahun 2016, maka putusan praperadilan tidak dapat diupayakan hukum. Upaya yang dapat dilakukan untuk memeriksa kejanggalan ratio decidendi Hakim praperadilan adalah dengan melakukan tinjauan kritis. Oleh karenanya, penelitian ini menggunakan tinjauan kritis untuk menganalisis Putusan Nomor 97/Pid.Prap/2017/PN.Jkt.Sel, yang memutus bahwa penetapan Tersangka Setya Novanto tidak sah. Fokus kajian adalah pada pertimbangan Hakim yang menyatakan bahwa penyidikan dilakuan tanpa melalui penyelidikan dan alat bukti pada perkara orang lain tidak dapat digunakan untuk orang lain.

Pemilihan Putusan Nomor: 97/Pid.Prap/2017/PN.Jkt.Sel sebagai objek penelitian didasarkan pada aktualisasi putusan, menimbulkan reaksi ketidaksetujuan banyak pihak dan tentunya terdapat kejanggalan pada pertimbangan hukumnnya. Tinjauan kritis terhadap putusan $а$ quo bertujuan untuk menentukan sejauhmana kesesuaian antara pertimbangan hukum dengan peraturan perundang-undangan yang berkaitan.

Berdasarkan uraian latar belakang di atas, maka perumusan masalah yang mengarah pada tinjauan kritis Putusan Praperadilan Nomor 97/Pid.Prap/2017/PN.Jkt.Sel yang memutus bahwa penetapan Tersangka atas Setya Novanto adalah tidak sah, dirumuskan sebagai berikut:

1. Bagaimana penetapan tersangka tindak pidana korupsi oleh Komisi Pemberantasan Korupsi yang tidak melalui proses penyelidikan (Studi Kasus Putusan Praperadilan No. 97/Pid.Prap/2017/PN. Jkt.Sel)?

2. Bagaimana alat bukti yang digunakan oleh Komisi Pemberantasan Korupsi pada tahap penyelidikan dan penyidikan untuk 
menetapkan status seseorang menjadi Tersangka tindak pidana korupsi (Studi Kasus Putusan Praperadilan Nomor: 97/Pid.Prap/2017/PN.Jkt.Sel)?

\section{METODE PENELITIAN}

Metode penelitian yang digunakan adalah penelitian yuridis normatif. Hal tersebut sebagai konsekuensi atas dipilihnya Putusan Nomor: 97/Pid.Prap/2017/PN.Jkt.Sel sebagai objek penelitian dan permasalahan yang berfokus pada kejanggalan ratio decidendi pada putusan a quo. Metode penelitian yuridis normatif ini digunakan untuk menemukan kebenaran mengenai keabsahan penetapan Tersangka tindak pidana korupsi dan alat bukti yang digunakan untuk menetapkan status seseorang sebagai Tersangka tindak pidana korupsi. Kebenaran ditemukan berdasarkan pada logika keilmuan hukum dari sisi normatifnya. Metode pengumpulan data yang digunakan bergantung pada bahan hukum primer berupa peraturan perundang-undangan, bahan hukum sekunder berupa buku, jurnal hukum, yurisprudensi/putusan pengadilan dan pendapat ahli serta bahan hukum tersier, berupa artikel, kamus hukum dan petunjuk lain yang diperlukan.

\section{HASIL PENELITIAN DAN PEMBAHASAN}

\section{Penetapan Tersangka Tindak Pidana Korupsi yang Tidak Melalui Proses Penyelidikan}

Secara filosofis, penegakan hukum pidana harus dilaksanakan dalam rangka pencapaian keadilan. Penegakan hukum pidana harus dilakukan secara hati-hati. Oleh karenanya, diberlakukanlah asas due process of law dan asas legalitas dalam hukum acara pidana. Due process of law menghasilkan prosedur dan substansi yang memberikan perlindungan hukum terhadap individu. ${ }^{98}$ Sementara asas legalitas mengandung makna lex scripta (tertulis), lex certa (jelas) dan lex stricta (hukum pidana ditafsirkan secara ketat). Legisme ini cenderung mengesampingkan kebenaran materil. ${ }^{99}$ Menarik korelasi dengan objek permasalahan, maka legisme menyasar pada UU No. 31 Tahun 1999 yang telah diubah melalui UU No. 20 Tahun 2001 dan UU No. 30 Tahun 2002. Sementara due process of law diwujudkan melalui mekanisme praperadilan.

Secara yuridis, penyelidikan tindak pidana korupsi harus mengindahkan KUHAP, UU PTPK dan UU KPK. Berdasarkan Pasal 1 angka 5 KUHAP, penyelidikan merupakan serangkaian kegiatan yang dilakukan untuk menemukan peristiwa pidana. Penyelidikan terhadap kasus korupsi e-KTP telah didahului dengan pengawasan yang dilakukan oleh KPK. Pada masa pengawasan tersebut, ditemukan kejanggalan, diantaranya pada saat uji coba ada penetapan Tersangka oleh Kejaksaan yang tidak dilanjutkan, temuan post bidding (bertentangan dengan Perpres No. 54 Tahun 2010 dan Keppres No. 80 Tahun

98 Rhonda Wasserman, "Procedural Due Process: A Reference Guide to the United States Constitution", Greenwood Publishing Group, Santa Barbara, 2004, hlm. 1 dikutip dalam Eddy O. S. Hiariej, "Teori dan Hukum Pembuktian", Erlangga, Jakarta, 2012, hlm. 30.

99 Eddy O. S. Hiariej, "Teori dan Hukum Pembuktian", Erlangga, Jakarta, 2012, hlm. 37. 
2003) dan penandatanganan kontrak sanggah banding pada saat complain peserta lelang belum selesai. Atas temuan tersebut, KPK melakukan penyelidikan dengan berdasarkan Sprin.Lidik 53/07/2013, tertanggal 26 Juli 2013.

Selama penyelidikan, KPK melakukan identifikasi perkara yang menunjukkan bahwa proyek e-KTP merupakan proyek nasional, melibatkan Kementerian Dalam Negeri yang menjalankan fungsi perencanaan dan pelaksanaan, DPR RI yang menjalankan fungsi penganggaran dan konsorsium perusahaan pemenang lelang yang menjalankan fungsi pengadaan barang dan jasa. Pada proses penyelidikan, KPK melakukan pemanggilan saksi, meminta keterangan ahli dan mengumpulkan dokumen yang relevan dengan proyek e-KTP. Akhirnya, KPK berhasil memperoleh alat bukti berupa 62 keterangan saksi dan lebih dari 457 dokumen.

Sebelum dilakukan penyidikan, dilakukan gelar perkara pada tanggal 17 Februari 2014 yang menghasilkan Laporan Hasil Penyelidikan No. LHP14/22/03/2014, tertanggal 17 Maret 2014. Pada laporan hasil penyelidikan tersebut, termuat pula perhitungan keuangan negara sebesar Rp. 1,1 T. Selanjutnya, KPK melakukan penyidikan terhadap Sugiharto. Hasil penyidikan mengarah pada keterlibatan pihak lain. Oleh karenanya, KPK juga turut melakukan penyidikan terhadap Irman, Andi Narogong als. Andi Agustinus, termasuk pula penyidikan terhadap Setya Novanto. Penyidikan terhadap Setya Novanto dilakukan didasarkan pada Sprin.Dik 56/01/07/2017 tertanggal 17 Juli 2017 dan SPDP 310/23/07/2017, tertanggal 18 Juli 2017.

Peristiwa di atas menunjukkan bahwa penyelidikan yang dilakukan pada Juli 2013 digunakan sebagai dasar untuk melakukan penyidikan dan penetapan Tersangka terhadap beberapa orang. UU PTPK, UU KPK maupun KUHAP tidak menentukan secara eksplisit legitimasi penyelidikan yang digunakan untuk melakukan beberapa penyidikan. Namun, hal tersebut dibenarkan dalam pandangan beberapa praktisi.

Lukhar Syan'in menyatakan bahwa pada tindak pidana korupsi yang telah terindentifikasi dilakukan secara bersama-sama, suatu proses penyelidikan dapat dijadikan dasar untuk melakukan penyidikan atas beberapa orang yang diduga sebagai Tersangka. ${ }^{100}$ Raden Prabowo Ajisasmito mengungkapkan bahwa dalam pengelolaan keuangan negara tidak hanya melibatkan satu pihak. Artinya, penyelidikan tindak pidana korupsi tidak berfokus pada salah seorang saja, melainkan berfokus pada tindak pidana korupsi. Dengan demikian dapat dirunut siapa saja yang terlibat dalam perwujudan deliknya. Atas dasar tersebut, maka penyelidikan tindak pidana korupsi dapat digunakan sebagai dasar untuk dilakukannya penyidikan atas beberapa orang. ${ }^{101}$

Selain itu berdasarkan pada pandangan monistis perbuatan pidana, Simons menyebutkan bahwa strafbaar feit terdiri atas unsur objektif dan unsur

\footnotetext{
${ }^{100}$ Luk Har Syan'in, "Wawancara Pribadi", Kepala Unit Tindak Pidana Korupsi Kepolisian Resor Kudus, 15 Maret 2018, Kepolisian Resor Kudus.

${ }^{101}$ Raden Prabowo Ajisasmito, "Wawancara Pribadi”, Kepala Seksi Tindak Pidana Khusus Kejaksaan Negeri Kudus, 26 Maret 2018, Kejaksaan Negeri Kudus.
} 
subjektif. Unsur objektif terdiri atas perbuatan, akibat perbuatan dan kemungkinan adanya keadaan tertentu yang menyertai perbuatan. Unsur subjektif, meliputi orang yang mampu bertanggungjawab dan adanya kesalahan (dolus atau culpa). ${ }^{102}$ Berdasarkan pandangan tersebut, penyelidikan yang ditujukan untuk membuktikan ada atau tidaknya tindak pidana juga termasuk pula untuk menemukan unsur subjektif (orang yang melakukan perbuatan pidana). Artinya, ketika penyelenggaraan penyelidikan dilakukan juga untuk mengidentifikasi siapa saja yang menjadi calon Tersangka dibenarkan.

Dengan demikian, maka berdasarkan Pasal 1 angka 5 KUHAP, Pasal 1 angka 2 KUHAP, Pasal 44 ayat (1) dan ayat (2) UU No. 30 Tahun 2002, Putusan MK No. 21/PUU$\mathrm{XII} / 2014$, serta terpenuhinya manajemen penyelidikan dan manajeman penyidikan, didukung pula dengan keterangan praktisi dan dibenarkan melalui pandangan monistis perbuatan pidana, maka mematahkan pertimbangan hukum Hakim praperadilan yang menyatakan bahwa penyidikan terhadap Setya Novanto dilakukan tanpa melalui penyelidikan.

Selanjutnya, Peneliti mengkritisi penalaran Hakim Praperadilan yang menyatakan bahwa dalam melakukan penetapan Tersangka harus memenuhi adanya 2 (dua) alat bukti, calon Tersangka dan pada tahap akhir penyidikan. Sebagaimana telah diuraikan sebelumnya bahwa Penyidik telah menemukan dua jenis alat bukti

\footnotetext{
102 Sudarto, "Hukum Pidana I", Yayasan Sudarto Fakultas Hukum Undip, Semarang, 1990, hlm. 41.
}

berupa keterangan saksi dan surat ditambah dengan alat bukti yang ditemukan pada saat melakukan penyidikan terhadap Sugiharto, Irman dan Andi Agustinus als. Andi Narogong. Mengenai calon Tersangka, Febridiansyah, Juru Bicara KPK menyatakan bahwa pada tahap penyelidikan KPK telah memiliki deret nama yang patut diduga sebagai Tersangka. Prasyarat ketiga yang menyebutkan bahwa penetapan Tersangka dilakukan pada tahap akhir penyidikan. Sesungguhnya Pasal 1 angka 2 KUHAP tidak memberikan pemahaman baik secara eksplisit maupun implisit bahwa ada pembagian tahap penyidikan. Pada tataran praktis, Luk Har Syan'in dan Raden Prabowo Ajisasmito pun tidak mengenal adanya pembagian tahap penyidikan.

Selain secara filosofis dan yuridis, kajian kritis juga perlu dilakukan dalam sudut pandang sosiologis. KUHAP, UU PTPK maupun UU KPK tidak mewajibkan Penyidik untuk terlebih dahulu memperlihatkan bukti yang telah diperoleh kepada orang yang akan diperiksa. Tetapi doktrin menyebutkan bahwa hal tersebut diperlukan untuk mencegah unfair prejudice atau persangkaan yang tidak wajar. ${ }^{103}$ Penetapan Tersangka harus melalui pemeriksaan terlebih dahulu, Calon Tersangka diberi kesempatan mengajukan saksi, bukti dan jika perlu ahli. $^{104}$ Konfrontasi tersebut diperlukan, manakala Penyidik belum

\footnotetext{
${ }^{103}$ Arthur Best, "Evidence: Examples and Explanations", Little, Brown and Company, London, 1994, hlm. 4 dikutip dalam dalam Eddy O. S. Hiariej, "Teori dan Hukum Pembuktian", Erlangga, Jakarta, 2012, hlm. 98.

${ }^{104}$ Mudzakkir, "Indonesia Lawyers Club: Novanto, Wow!", 3 Oktober 2017, ILC TV One, Jakarta.
} 
meyakini bahwa seorang patut ditetapkan sebagai Tersangka meskipun bukti permulaan telah ada.

Berdasarkan elaborasi terhadap aspek filosofis, aspek yuridis dan aspek sosiologis, maka Peneliti berkesimpulan bahwa ratio decidendi Hakim praperadilan yang menyatakan bahwa penetapan Tersangka atas Setya Novanto dilakukan tanpa didahului dengan penyelidikan adalah pertimbangan hukum yang tidak tepat. Ratio decidendi yang menyebutkan bahwa penetapan Tersangka harus dilakukan pada tahap akhir penyidikan juga bukan merupakan alasan yang berdasarkan hukum. Kedua argumentasi tersebut, tidak sesuai dengan ketentuan sebagaimana dimaksud dalam Pasal 44 ayat (1) dan ayat (2) jo. Pasal 46 ayat (1) UU No. 30 Tahun 2002, Pasal 1 angka 2, 5 dan 14 KUHAP serta Putusan MK No. 21/PUU-XII/2014.

2. Alat Bukti yang Digunakan oleh Komisi Pemberantasan Korupsi pada Tahap Penyelidikan dan Penyidikan Untuk Menetapkan Status Tersangka

Berdasarkan hasil analisis sebelumnya, telah disimpulkan bahwa penyelidikan yang dilakukan oleh KPK dapat digunakan sebagai dasar untuk dilakukannya penyidikan terhadap beberapa orang. Artinya bahwa alat bukti yang digunakan pada perkara orang lain pun dapat digunakan pada perkara orang lain pula. Termasuk digunakan pula untuk menetapkan orang lain sebagai Tersangka. Namun dengan prasyarat bahwa alat bukti yang dimiliki oleh Penyidik memiliki relevansi terhadap orang yang akan disidik serta diyakini bahwa tindak pidana korupsi e-KTP dilakukan secara bersama-sama. Alat bukti yang demikian diukur dengan menggunakan parameter pembuktian, meliputi bewijsmiddelen (alat bukti), bewijsvoering (perolehan alat bukti), bewijslast (beban pembuktian) dan bewijskracht (kekuatan pembuktian).

Bewijsmiddelen yang digunakan oleh Penyidik dalam menetapkan Setya Novanto sebagai Tersangka haruslah membuktikan unsur tindak pidana korupsi pada Pasal 2 ayat (1) dan Pasal 3 UU No. 20 Tahun 2001 sebagaimana dipersangkakan. Unsur perbuatan melawan hukum ditunjukkan melalui intervensi Setya Novanto dengan menemui vendor untuk menentukan jenis barang dan harga yang menyebabkan terjadinya kemahalan. Diketahui bahwa Setya Novanto merupakan lead konsorsium peserta lelang e-KTP. Setya Novanto telah melakukan perbuatan yang bertentangan dengan Pasal 5 Perpres No. 54 Tahun 2010. Unsur penyalahgunaan wewenang dilakukan Setya Novanto dengan menggunakan pengaruhnya sebagai Ketua Fraksi Golkar melibatkan Andi Agustinus als. Andi Narogong dalam pembahasan anggaran. Unsur memperkaya diri sendiri ditunjukkan dengan adanya fakta bahwa Setya Novanto menerima fee sebesar $7 \%$ dari nilai proyek. Laporan hasil audit BPKP menunjukkan bahwa pelaksanaan proyek mengakibatkan kerugian Negara sebesar Rp. 2,3 T. Artinya, fee yang diterima oleh Setya Novanto (yang berasal dari keuangan Negara) turut menimbulkan kerugian keuangan Negara.

Berdasarkan serangkaian pembuktian tersebut, diketahui bahwa Setya Novanto masuk dalam klasifikasi turut serta melakukan perbuatan tindak 
pidana korupsi yang berkedudukan sebagai intellectual dader. Terkumpul pula alat bukti berupa keterangan saksi, keterangan ahli dan lebih dari 1.100 dokumen. Dengan demikian, maka parameter bewijsmiddelen terpenuhi, termasuk bewijsminimmum (bukti minimum), dengan perhitungan sebagai berikut:

a. secara kuantitatif, terdapat 62 alat bukti keterangan saksi, 5 alat bukti keterangan ahli dan 1 alat bukti surat (berapapun banyak surat dihitung 1), jumlahnya 68 alat bukti;

b. secara kualitatif, terdapat alat bukti keterangan saksi, alat bukti keterangan ahli dan alat bukti surat, artinya telah terpenuhi adanya 3 jenis alat bukti.

Selanjutnya analisis dilakukan menggunakan parameter bewijsvoering. Penyelidikan yang dilakukan KPK terhadap korupsi eKTP didasarkan Sprin.Lidik 53/07/2013, tertanggal 26 Juli 2013. Berdasarkan penyelidikan tersebut, KPK memperoleh keterangan dari 62 saksi dan lebih dari 457 dokumen. Selanjutnya, KPK melakukan gelar perkara yang menghasilkan LHP14/22/03/2014, tertanggal 17 Maret 2014 dan LKTPK-15/KPK/03/2014, tertanggal 17 Maret 2014. Penyelidikan telah memenuhi administrasi penyelidikan dan alat bukti dinyatakan sebagai lawful legal evidence atau alat bukti yang sah perolehannya.

Penyidik juga menggunakan alat bukti yang berasal dari penyidikan orang lain, sehingga perlu dikritisi apakah alat bukti yang diperoleh pada penyidikan orang lain juga dapat dikategorikan sebagai lawful legal evidence. Diketahui bahwa penyidikan yang dilakukan baik terhadap
Sugiharto, Irman dan Andi Narogong dilakukan berdasarkan surat perintah penyidikan dan laporan hasil penyelidikan. Penyidikan terhadap Sugiharto didasarkan Sprin.Dik16/01/04/2014 tertanggal 17 April 2014 dan LKTPK-15/KPK/03/2014, tertanggal 17 Maret 2014. Penyidikan terhadap Irman didasarkan pada Sprin.Dik 69/01/09/2016, tertanggal 21 September 2016 dan Laporan Pengembangan Penyidikan No: LPP12/23/09/2016, tertanggal 15 September 2016. Penyidikan terhadap Andi Agustinus als. Andi Narogong didasarkan pada: Sprin.Dik 20/01/03/2017, tertanggal 21 Maret 2017 dan Laporan Pengembangan Penyidikan tertanggal 28 Februari 2017. Dengan demikian, maka alat bukti yang ditemukan pada penyidikan atas Sugiharto, Irman dan Andi Narogong adalah alat bukti yang sah perolehannya.

Sekumpulan alat bukti dan barang bukti semakin mengarah pada keterlibatan Setya Novanto sebagai intellectual dader. Setelah melalui gelar perkara pada tanggal 21 Juni 2017 yang dituangkan ke dalam Laporan Pengembangan Penyidikan Nomor: LPP-15/23/07/2017, tertanggal 17 Juli 2017, KPK memutuskan untuk melakukan penyidikan kepada Setya Novanto dan menetapkan Setya Novanto sebagai Tersangka. Penyidikan ditandai dengan adanya Sprin.Dik 56/01/07/2017, tertanggal 17 Juli 2017 dan Surat Pemberitahuan Dimulainya Penyidikan melalui Surat Nomor B-310/23/07/2017, tertanggal 18 Juli 2017.

Terhadap parameter bewijskracht, Peneliti tidak dapat menentukan apakah alat bukti memiliki kekuatan pembuktian atau tidak, karena pada 
persidangan Hakim lah yang memiliki otoritas untuk menilai alat bukti. Namun, Peneliti akan mengkritisi apakah pembuktian telah dilakukan secara berimbang (bewijslast).

KUHAP, Putusan MK No. 21/PUU-XII/2017 dan PERMA No. 4 Tahun 2016 tidak mengatur mengenai sistem pembuktian pada praperadilan, sehingga tidak diketahui pula ideal pembagian beban pembuktiannya. Pada hukum acara perdata dikenal asas actori in cumbit probatio, yang berarti siapa saja yang menggugat berkewajiban untuk membuktikannya. Hal tersebut diatur secara eksplisit dalam Pasal 1865 Kitab UndangUndang Hukum Perdata. Pada hukum acara pidana dikenal asas actori incumbit onus probandi. ${ }^{105}$ Artinya, pihak yang menuntut berkewajiban untuk membuktikan. Sementara, pada perkara tindak pidana korupsi dikenal sistem pembalikan beban pembuktian. Lantas asas pembuktian manakah yang tepat untuk digunakan pada pemeriksaan di sidang praperadilan ? Pada hakikatnya antara asas actori in cumbit probatio dan asas actori incumbit onus probandi adalah sama, yang membedakan hanyalah pada para pihak yang berperkara. Artinya letak pertanyaan lebih berfokus pada siapa yang berkewajiban untuk membuktikan apakah Pemohon atau Termohon.

Pada praperadilan, Pemohonlah yang mendalilkan bahwa penetapan Tersangka bertentangan dengan undang-undang, maka Pemohonlah, yang berkewajiban untuk membuktikan kebenarannya. Di sisi lain, Termohon juga harus mempersiapkan tangkisan. Menurut Lilik Mulyadi, maka sistem pembuktian yang demikian disebut

${ }^{105}$ Eddy O. S. Hiariej, Op. Cit., hlm. 43. dengan sistem beban pembuktian biasa/konvensional. ${ }^{106}$

Pembuktian pada praperadilan Setya Novanto telah mengindahkan sistem pembuktian sebagaiman dimaksud, namun tidak melakukan pemeriksaan secara komprehensif. Hakim menolak untuk melakukan pemeriksaan terhadap alat bukti rekaman yang digunakan KPK sebagai dasar melakukan penetapan Tersangka dengan alasan memasuki pokok perkara. Hal tersebut menunjukkan bahwa Hakim tidak melakukan pembuktian yang mencakup relevansi alat bukti terhadap orang yang dipersangkakan. Penolakan alat bukti rekaman, secara tidak langsung juga menunjukkan bahwa Hakim tidak memberikan ruang yang proporsional terhadap masing-masing pihak. Dengan kata lain, Hakim praperadilan tidak menerapkan asas audi et alteram partem.

Berdasarkan pada uraian di atas, maka Peneliti berkesimpulan bahwa alat bukti pada perkara orang lain dapat digunakan untuk melakukan penyidikan dan penetapan Tersangka terhadap orang lain apabila tindak pidana korupsi dilakukan bersamasama atau terdapat unsur turut serta dalam perwujudan deliknyya. Selain itu, juga memenuhi parameter pembuktian, meliputi bewijsmiddelenbewijsminimmum, bewijsvoering, bewijskracht dan bewijslast. Dengan kata lain, penetapan Setya Novanto sebagai Tersangka adalah sah.

\footnotetext{
106 Lilik Mulyadi, "Pembalikan Beban Pembuktian Tindak Pidana Korupsi”, Alumni, Bandung, 2007, hlm. 103.
} 


\section{Kesimpulan}

a. Penetapan Tersangka tindak pidana korupsi oleh KPK dilakukan tidak melalui proses penyelidikan, disimpulkan sebagai berikut:

1) Penetapan Tersangka terhadap Setya Novanto telah didahului penyelidikan berdasarkan Sprin.Lidik 53/07/2013, 26 Juli 2013.

2) Suatu penyelidikan dapat digunakan sebagai dasar melakukan penyidikan dan penetapan Tersangka terhadap beberapa orang, apabila perwujudan delik korupsi dilakukan bersa-sama.

3) Penetapan Setya Novanto sebagai Tersangka adalah sah, karena telah dilakukan sesuai Pasal 1 angka 2 dan 5 KUHAP, Pasal 44 ayat (1) dan ayat (2) UU No. 30 Tahun 2002, Putusan MK No. 21/PUUXII/2014 serta terpenuhinya manajemen penyelidikan dan penyidikan.

b. Alat bukti yang digunakan oleh KPK pada tahap penyelidikan dan penyidikan untuk menetapkan status seseorang menjadi Tersangka tindak pidana korupsi.

1) Alat bukti pada perkara orang lain dapat digunakan sebagai dasar melakukan penetapan Tersangka terhadap orang lain.

2) Penggunaan alat bukti pada perkara orang lain sah, apabila memenuhi parameter bewijsmiddelen, bewijsvoering dan bewijskracht.

3) Pembuktian praperadilan yang memeriksa keabsahan penetapan Tersangka Setya
Novanto dilakukan secara parsial dan belum berimbang.

\section{Saran}

a. Bagi KPK

1) Optimalisasi prinsip kehatihatian dalam melakukan penetapan Tersangka melalui Penyelidik KPK memberikan laaporan hasil penyelidikan secara utuh kepada Pimpinan KPK.

2) Dilakukan konfrontasi bukti permulaan yaang cukup dengan calon Tersangka sebelum melakukan penetapan Tersangka tindak pidana korupsi.

b. Bagi Hakim Praperadilan

1) Tidak menolak memeriksa bukti permulaan yang digunakan sebagai dasar penetapan Tersangka tindak pidana korupsi.

2) Memeriksan kualitas alat bukti dan relevansi alat bukti dengan orang yang dipersangkakan

c. Bagi Mahkamah Agung

1) Membentuk PERMA yang mengatur beracaranya praperadilan pada keabsahan penetapan Tersangka.

2) Melakukan eksaminasi secara berkala.

\section{DAFTAR PUSTAKA}

Hiariej, Eddy. O. S. 2012. Teori dan Hukum Pembuktian. Jakarta: Erlangga.

Ibrahim, Johnny. 2005. Teori \& Metodologi Penelitian Hukum Normatif. Jakarta: Banyumedia Publishing. 
Muhammad, Abdulkadir. 2004. Hukum

dan Penelitian Hukum. Bandung:

Citra Aditya Bakti.

Mulyadi, Lilik. 2007. Pembalikan

Beban Pembuktian Tindak Pidana

Korupsi. Bandung: Alumni.

Soemitro, Ronny Hanitijo. 1988.

Metodologi Penelitian Hukum dan

Jurimetri. Semarang: Ghalia

Indonesia.

Sudarto. 1990. Hukum Pidana I.

Semarang: Yayasan Sudarto

Fakultas Hukum Undip.

Wignjosoebroto, Soetandjo. 2013.

Metode Penelitian Hukum

Konstelasi dan Refleksi. Jakarta:

Yayasan Pustaka Obor Indonesia.

\section{Peraturan Perundang-Undangan}

Undang-Undang Republik Indonesia Nomor 8 Tahun 1981 tentang Hukum Acara Pidana

Undang-Undang Republik Indonesia Nomor 14 Tahun 1985 tentang Mahkamah Agung

Undang-Undang Republik Indonesia Nomor 31 Tahun 1999 tentang Pemberantasan Tindak Pidana Korupsi

Undang-Undang Republik Indonesia Nomor 20 Tahun 2001 tentang Perubahan atas Undang-Undang Republik Indonesia Nomor 31 Tahun 1999 tentang Pemberantasan Tindak Pidana Korupsi
Undang-Undang Republik Indonesia Nomor 30 Tahun 2002 tentang Komisi Pemberantasan Korupsi

Undang-Undang Republik Indonesia Nomor 5 Tahun 2004 tentang Perubahan atas Undang-Undang Republik Indonesia Nomor 14 Tahun 1985 tentang Mahkamah Agung

Undang-Undang Republik Indonesia Nomor 3 Tahun 2009 tentang Perubahan Kedua atas UndangUndang Republik Indonesia Nomor 14 Tahun 1985 tentang Mahkamah Agung

Undang-Undang Republik Indonesia Nomor 46 Tahun 2009 tentang Pengadilan Tindak Pidana Korupsi

Peraturan Presiden Republik Indonesia Nomor 54 Tahun 2010 tentang Pengadaan

Barang/Jasa Pemerintah

Peraturan Mahkamah Agung Republik Indonesia Nomor 4 Tahun 2016 tentang Larangan Peninjauan Kembali Putusan Praperadilan

Keputusan Presiden Republik Indonesia Nomor 80 Tahun 2003 tentang Pedoman Pelaksanaan Pengadaan Barang/Jasa Pemerintah 